\title{
Hyperglycemia Accelerated Endothelial Progenitor Cell Senescence via the Activation of p38 Mitogen-Activated Protein Kinase
}

\author{
Shintaro Kuki, MD; Toshio Imanishi, MD; Katsunobu Kobayashi, MD; \\ Yoshiki Matsuo, MD; Masahiro Obana, MD; Takashi Akasaka, MD
}

\begin{abstract}
Background Both the number and function of bone marrow-derived endothelial progenitor cells (EPCs) have been shown to be impaired in patients with diabetes mellitus. Therefore, we investigated the effect of glucose on the senescence of EPCs.

Methods and Results EPCs were isolated from human peripheral blood and characterized to evaluate the effect of glucose (in $5-12.5 \mathrm{mmol} / \mathrm{L}$ ) on the rate of senescence by acidic $\beta$-galactosidase staining. The phosphorylation of p38 mitogen-activated protein kinase (MAPK) level was analyzed by ELISA. The exposure of cultured EPC to high glucose (HG; $12.5 \mathrm{mmol} / \mathrm{L}$ ) significantly accelerated the rate of senescence compared with that in osmolar control (L-glucose) during 10 days culture. An inhibitory effect of HG on EPC proliferation disclosed by an MTS assay. The phosphorylation of p38 MAPK in EPCs was also increased by glucose compared with control in a dose-dependent manner. HG-induced EPC senescence was significantly inhibited by the addition of an inhibitor of the p38 MAPK, SB203580.

Conclusions HG accelerates the onset of EPCs senescence leading to the impairment of proliferative activity, which might be related to the phosphorylation of p38 MAPK. (Circ J 2006; 70: 1076-1081)
\end{abstract}

Key Words: Endothelial progenitor cell; Glucose; p38 mitogen-activated protein kinase; Senescence

C ardiovascular complications based on atherosclerosis are the leading causes of morbidity and mortality in patients with diabetes mellitus (DM), and the endothelial dysfunction might be the beginning of the athetosclerosis ${ }^{1-3}$ Because the onset and progression of complications are delayed in diabetic patients with good glycemic control, hyperglycemia is thought to be a key factor in the development of endothelial dysfunction? ${ }^{2}$ All forms of diabetes are characterized by chronic hyperglycemia and the development of diabetes-specific microvascular pathology in the retina, renal glomerulus and peripheral nerve.

Recent studies indicate that elevated glucose concentration can induce dysfunction of several intracellular signal transduction cascades, including modulation of protein kinase $\mathrm{C}$, generation of reactive oxygen species and accumulation of advanced glycation end products. Furthermore, it has been reported that high glucose (HG) levels can accelerate the p38 mitogen activated protein kinase pathway in endothelial cells? Mitogen-activated protein kinases (MAPKs) regulate cellular proliferation and differentiation induced by a variety of cellular stresses. MAPKs are the family of serine/threonine kinases that are divided 3 to major subgroups: extracellular signal-regulated kinase (ERK); c-jun N-terminal kinase; and p38 MAPK.

Recent insights suggest that the injured endothelial monolayer is regenerated by circulating bone marrow

(Received February 14, 2006; revised manuscript received May 9, 2006; accepted May 19, 2006)

Department of Cardiovascular Medicine, Wakayama Medical University, Wakayama, Japan

Mailing address: Toshio Imanishi, MD, Department of Cardiovascular Medicine, Wakayama Medical University, 811-1 Kimiidera, Wakayama 641-8510, Japan. E-mail: t-imani@wakayama-med.ac.jp
(BM)-derived endothelial progenitor cells (EPCs), which accelerate reendothelialization and limits atherosclerotic lesion formation- ${ }^{6-10}$ This beneficial property of BM-EPCs makes them attractive for cell therapy targeting the regeneration of ischemic tissue. In contrast, a reduction in circulating EPCs has been demonstrated in the presence of various risk factors for coronary artery disease (CAD), such as hyperlipidemia, hypertension, smoking, chronic renal failure, aging and DM!1-17 Whether such risks affect the $\mathrm{BM}$ production of EPCs or impair the function of EPCs remains to be determined.

Based on this information, we hypothesized that hyperglycemia may impair the function of BM-EPCs through p38 MAPK pathway. We further examined the effect of glucose on the senescence of EPCs. In addition, we investigated whether these effects would be improved by SB203580, an inhibitor of p38 MAPK.

\section{Methods}

Isolation of Mononuclear Cells (MNCs) and Cell Culture

EPCs were cultured according to a previously described technique!18,19 Briefly, peripheral blood (PB)-MNCs were isolated from healthy volunteers using density gradient centrifugation with a Histopaque 1077 (Sigma Chemical $\mathrm{Co}$, St Louis, MO, USA). After purification with 3 washing steps, $10 \times 10^{6}$ PB-MNCs were plated on fibronectin-coated 6-well plates. Cells were cultured in endothelial basal medium-2 (EBM-2) (Clonetics; Walkersville, MD, USA) with EGM-2MV single aliquots containing 5\% fetal bovine serum, vascular endothelial growth factor, fibroblast growth factor-2, epidermal growth factor, insulin-like growth factor and ascorbic acid. EPCs were treated with glucose in differ- 
A D-glucose $5 \mathrm{mmol} / \mathrm{L}$

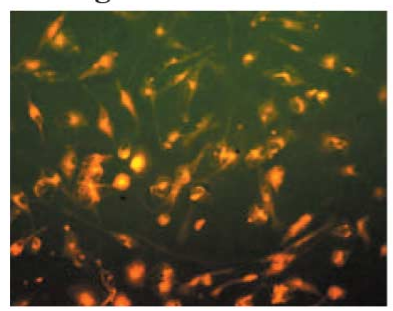

C

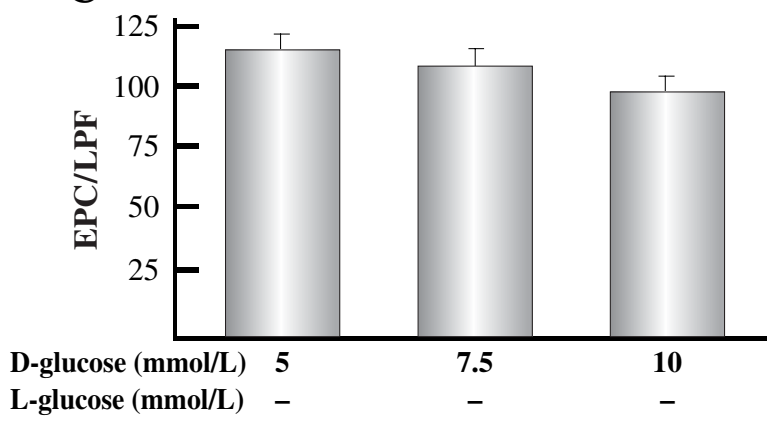

ent concentrations $(5,7.5,10$ and $12.5 \mathrm{mmol} / \mathrm{L})$. L-glucose was used as an osmolar control because it is known to have no impact on glucose metabolism. SB203580 $(1,10 \mu \mathrm{mol} / \mathrm{L}$, Promega, Madison, Wisconsin, USA), an inhibitor of p38 MAPK, was applied to hyperglycemic media containing $12.5 \mathrm{mmol} / \mathrm{L}$ D-glucose. After 4 days of culture, adherent cells were washed with medium and incubated with $2.4 \mathrm{~g} / \mathrm{ml}$ 1,1'-dioctadecyl-3, 3,3',3'-tetramethylindocarbocyaminelabeled acetylated low-density lipoprotein (acLDL) for $1 \mathrm{~h}$. Cells were fixed in $2 \%$ paraformaldehyde for $10 \mathrm{~min}$ and lectin staining was performed by incubation with isothiocyanate-labeled Ulex Europaeus agglutinin I (lectin; $10 \mu \mathrm{g} / \mathrm{ml}$; Sigma) for $1 \mathrm{~h}$. After staining, samples were viewed under an inverted fluorescent microscopy (Olympus, Tokyo, Japan). Dual-stained cells that were positive for lectin and acLDL were judged to be EPCs and these cells were counted per well. The number of EPCs per well was evaluated by counting 3 randomly selected low-power fields.

Senescence-Associated $\beta$-Galactosidase (SA $\beta$-gal) Activity Assay

EPCs were harvested 4 days after culture and re-seeded. Following adding of several concentrations of glucose into EPCs, EPCs at day 7 were harvested and then SA $\beta$-gal activity was measured as previously described 18 Briefly, EPCs were washed in phosphate buffered saline, fixed for $3 \mathrm{~min}$ (room temperature) in $2 \%$ paraformaldehyde, washed and incubated for $24 \mathrm{~h}$ at $37^{\circ} \mathrm{C}$ (no $\mathrm{CO}_{2}$ ) with fresh a SA$\beta$-gal stain solution $(1 \mathrm{mg} / \mathrm{ml}$ 5-bromo-4-chloro-3-indyl $\beta$ D-galactopyranoside, $5 \mathrm{mmol} / \mathrm{L}$ potassium ferrocyanide, $5 \mathrm{mmol} / \mathrm{L}$ potassium ferricyanide, $150 \mathrm{mmol} / \mathrm{L} \mathrm{NaCl}$, $2 \mathrm{mmol} / \mathrm{L} \mathrm{MgCl} 2,0.01 \%$ sodium deoxycholate and $0.02 \%$ Nonidet-40). EPCs were counterstained with 4',6-diaminophenylindole $(0.2 \mu \mathrm{g} / \mathrm{ml}$ in $10 \mathrm{mmol} / \mathrm{L}$ Tris-HCL, $\mathrm{pH} 7.0$, $10 \mathrm{mmol} / \mathrm{L}$ EDTA, $100 \mathrm{mmol} / \mathrm{L} \mathrm{NaCL}$ ) for $10 \mathrm{~min}$ to count the total cell number.

\section{Proliferative Activity Assay}

Mitogenic activity was assayed using a colorimetric MTS [3-(4,5-dimethylthiazol-2-yl)-5-(3-carboxymethoxyphe-
Fig 1. Glucose inhibits endothelial progenitor cells (EPCs) differentiation in human mononuclear cells (MNCs). MNCs were incubated with different glucose concentrations $(5,7.5,10,12.5 \mathrm{mmol} / \mathrm{L})$ for 4 days. Representative pictures of dual-stained EPCs (lectin (green) and acetylated low-density lipoprotein (red)) from control cultures (A) and high glucose (HG) culures (B) after 4 days. The number of differentiated, adherent EPCs in $\mathrm{HG}$ condition (D-glucose $12.5 \mathrm{mmol} / \mathrm{L}$ ) revealed significant decrease compared with control in a dose-dependent manner (C). Data are mean \pm SEM, $n=5, * p<0.01$ vs control. LPF, low-power fields.
nol)-2-(4-sulfophenyl)-2H-tetrazolium] assay (CellTiter 96 AQ:Promega, Madison, WI, USA). EPCs were harvested 4 days after culture and re-seeded with a 96-well plate $\left(1 \times 10^{4}\right.$ cells) in $0.1 \mathrm{ml}$ of EBM-2 medium. After 7 days in culture, MTS/phenazine methosulfate solution was added to each well for $3 \mathrm{~h}$, whereupon light absorbance at $490 \mathrm{~nm}$ was detected using an ELISA plate reader (Bionetics Laboratory, Kensington, MD, USA).

\section{Measurement of MAPKs}

For the analysis of the phosphorylation of either p38 MAPK or ERK1/2, a Cellular Activation of Signaling ELISA (CASETM) kit (SuperArray Bioscience Corp, Frederic, MD, USA) was used according to the manufacturer's protocol. In the CASE assay, EPCs were re-seeded onto a 96-well plate and cultured for 7 days. The cells were fixed with $4 \%$ formaldehyde to preserve any phosphorylation modification. Both anti-phospho-protein specific antibody $(\mathrm{Ab})$ and anti-pan-protein specific $\mathrm{Ab}$ were used as primary Abs. Following incubation with primary and secondary Abs, the amount of bound protein in each well was determined using a developing solution and an ELISA Plate Reader. The absorbance readings were then normalized to the relative cell number as determined by cell staining and an ELISA Plate Reader. The amount of phosphorylated protein, after normalization to the amount of total protein, was then used directly as an index of the degree of activation of the downstream pathway.

\section{Statistical Analysis}

Data were expressed as mean \pm SEM based on at least 5 independent experiments. Statistical analysis was performed by 1-way analysis of variance (analysis of variance test) for multiple testing. Probability values were considered significant at $\mathrm{p}<0.05$.

\section{Results}

Glucose Inhibits EPCs Differentiation in Human MNCs

The EPCs were characterized as adherent cells that were 

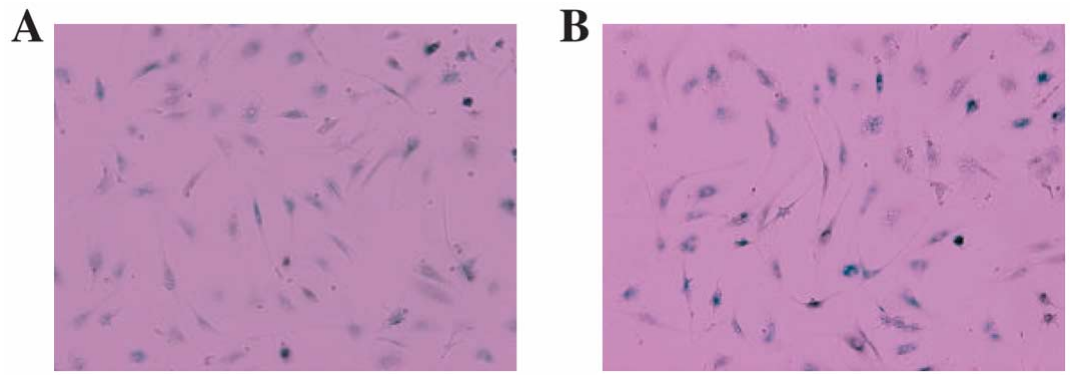

C<smiles>[Li]</smiles>

$$
\text { 造 }
$$

(\%)

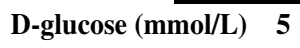

L-glucose $(\mathrm{mmol} / \mathrm{L}) \quad-$

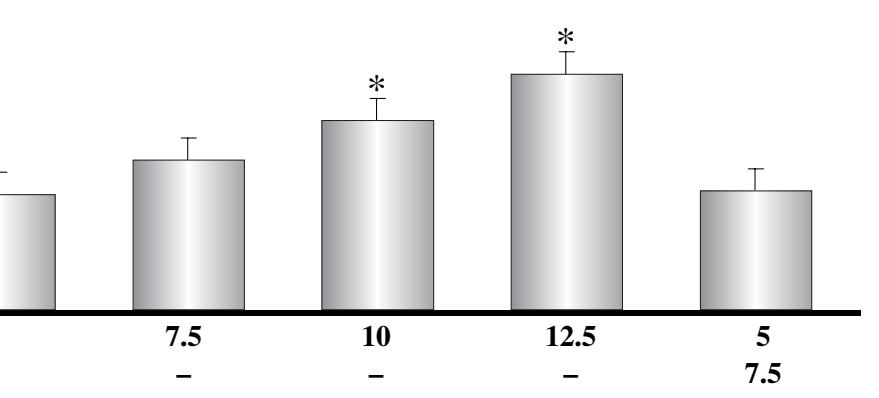

Fig 2. High glucose accelerates endothelial progenitor cells (EPCs) senescence. EPC senescence was evaluated by senescence-associated $\beta$-galactosidase (SA $\beta$-gal) staining. Representative photomicrographs show SA $\beta$-gal-positive cells (blue) in EPCs treated with different glucose concentrations (A: $5 \mathrm{mmol} / \mathrm{L}$; B: $12.5 \mathrm{mmol} / \mathrm{L}$ ). (C) At day 7 after culture, the number of SA $\beta$-gal positive cells was counted manually from a total of 200 cells. Data are expressed as mean \pm SEM $(\mathrm{n}=5) .{ }^{*} \mathrm{p}<0.01$ compared with control.

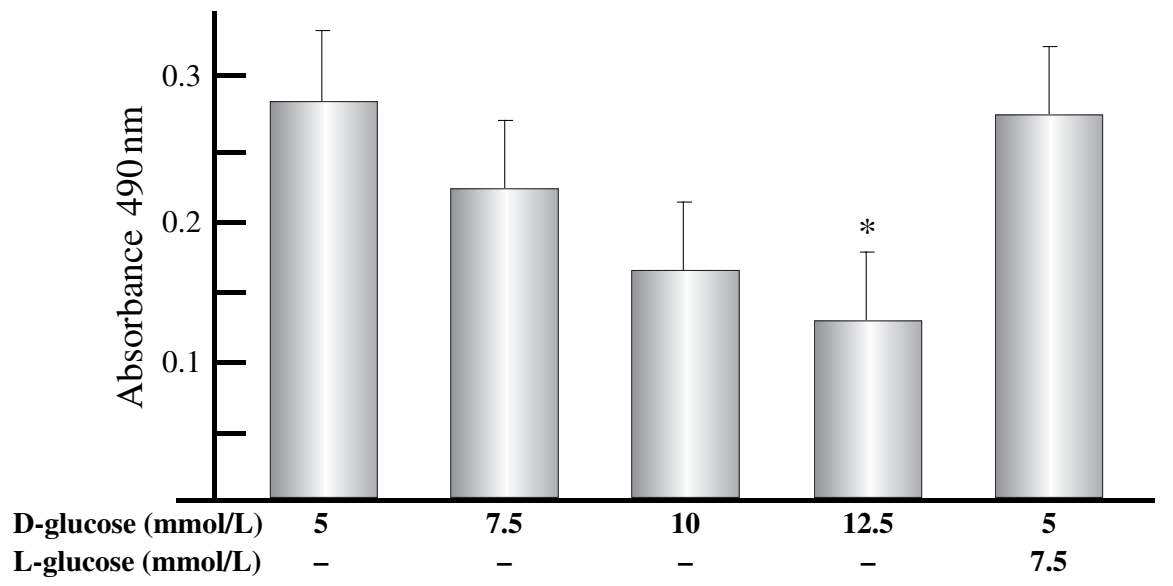

Fig 3. Glucose impairs mitogenic activity in endothelial progenitor cells (EPCs). At day 7 after culture, the mitogenic activity was detected as described in the methods. Data are expressed as mean \pm SEM $(n=5)$. $* p<0.01$ compared with control. double positive for both lectin and acLDL uptake. We examined the effect of glucose on EPCs differentiation. MNCs were incubated with different glucose concentrations $(5,7.5,10$ and $12.5 \mathrm{mmol} / \mathrm{L})$ for 4 days. The number of differentiated, adherent EPCs in HG condition revealed significant a decrease compared with controls in a dosedependent manner. L-glucose, as an osmolar control, did not affect EPC differentiation (Fig 1).

\section{Glucose Accelerates EPCs Senescence}

To assess the onset of senescence, acidic $\beta$-galactosidase was detected as a biochemical marker for acidification for the onset of cellular senescence. Co-incubation with glucose accelerated the increase in SA $\beta$-Gal-positive cells dosedependently (Figs 2A,B).

\section{Glucose Impairs Mitogenic Activity in EPCs}

Having demonstrated that glucose accelerated the onset of senescence, we examined whether it translated into an impairment of mitogenic activity in EPCs. MTS assay disclosed a significantly inhibitory effect of glucose on EPC proliferation at day 7 (Fig 3).

\section{Glucose Induces Phosphorylation of MAPKs}

The phosphorylated levels of MAPKs in EPCs were evaluated using CASE assay. Incubation of EPCs with glucose increased p38 and ERK1/2 activity dose-dependently (Fig 4).

\section{SB203580 Increases the Number of EPCs and Reduces Glucose-Induced EPC Senescence}

Having demonstrated that glucose increases p38 activity, we investigated the effect of the p38 inhibitor on EPCs differentiation in human MNCs. SB203580 significantly recovered glucose-induced reduction of a number of EPCs (Fig 5). Likewise, the glucose-induced increase in SA $\beta$ Gal-positive cells was significantly attenuated through treatment with SB203580 (Fig 6). In contrast, PD 98059, an inhibitor of ERK 1/2, had no effect on HG-induced EPC senescence.

\section{Discussion}

Recent studies have provided increasing evidence that the functional regeneration of ischemic tissue by improved neovascularization and possibly tissue repair is critically 
A

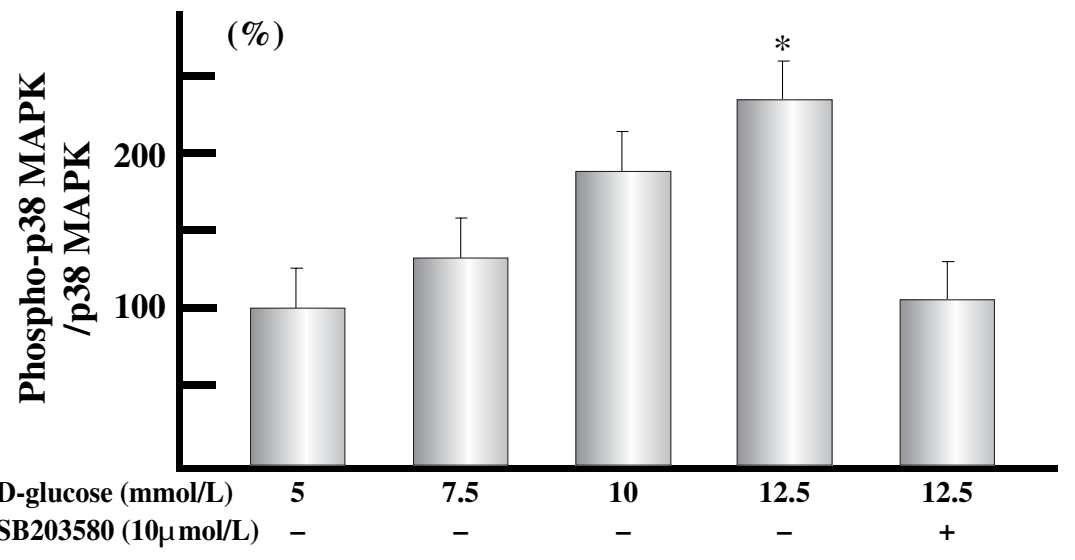

B

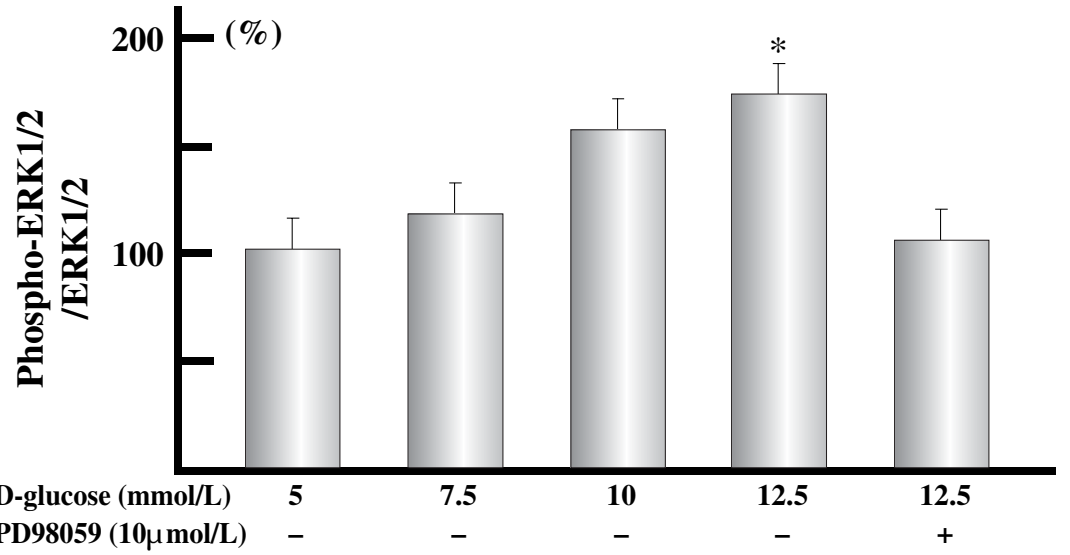

Fig 4. Effect of glucose on mitogen-activated protein kinases (MAPKs) phosphorylation in endothelial progenitor cells (EPCs). (A) Incubation of EPCs with glucose dosedependently increased p38-phosphorylation. The levels of phophorylated p38 MAPK in the control cells were defined as $100 \%$. (B) Glucose activated the MAPK extracellular signal-regulated kinase (ERK)1/2 dose-dependently. Data are expressed as mean \pm SEM ( $n=5)$. *p<0.01 compared with control.
Control (glucose $5 \mathrm{mmol} / \mathrm{L}$ )

HG + SB203580 $(1 \mu \mathrm{mol} / \mathrm{L})$

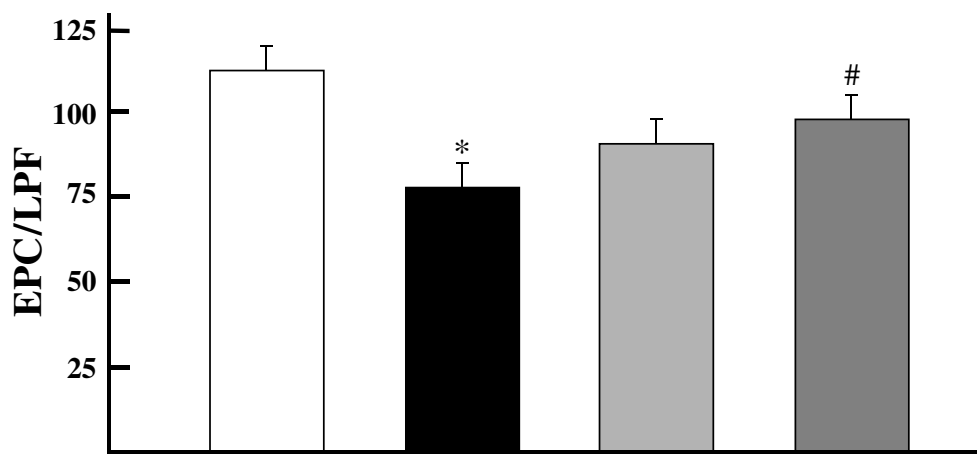

Control (glucose $5 \mathrm{mmol} / \mathrm{L}$ )

HG + SB203580 $(1 \mu \mathrm{mol} / \mathrm{L})$

HG + PD98059 $(10 \mu \mathrm{mol} / \mathrm{L})$

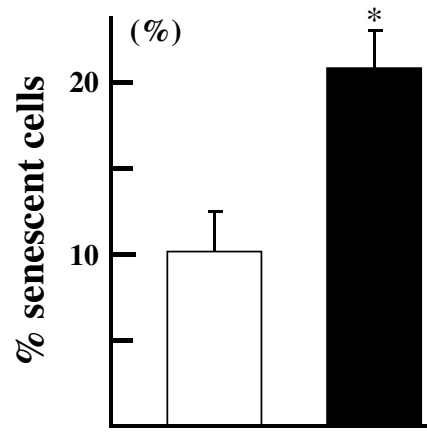

HG (glucose $12.5 \mathrm{mmol} / \mathrm{L}$ )

HG + SB203580 $(10 \mu \mathrm{mol} / \mathrm{L})$

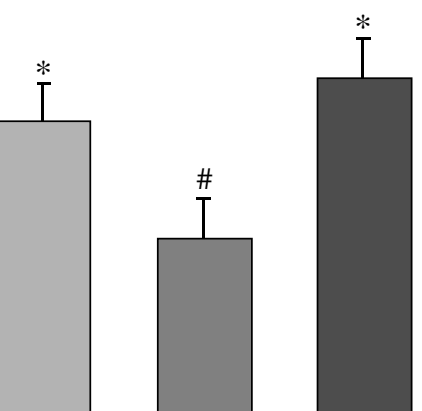

Fig 5. SB203580 increases the number of endothelial progenitor cells (EPCs). Treatment with SB203580 prevented high glucose (HG)-induced reduction of the number EPCs. Data are expressed as mean \pm SEM $(n=$ 5). ${ }^{*} \mathrm{p}<0.01$ compared with control; ${ }^{\#} \mathrm{p}<0.01$ compared with $\mathrm{HG}$.
Fig 6. SB203580 reduces glucose-induced endothelial progenitor cell senescence. The high glucose (HG)induced increase in senescence-associated $\beta$-galactosidase-positive cells was significantly attenuated by the co-treatment with SB203580. Data are expressed as mean \pm SEM $(n=5) . * p<0.01$ compared with control; ${ }^{\#} \mathrm{p}<0.01$ compared with HG. 
dependent on the mobilization and integration of EPC into the ischemic tissue. There are no specific studies in the literature on therapeutic revascularization with cell therapy for diabetic patients, although many studies have demonstrated that diabetic patients displayed poorer responses to cell therapy than non-diabetic patients ${ }^{20-30}$ Indeed, Tamarat et al demonstrated a reduced angiogenic potential of EPCs in diabetic animals. Administration of diabetic progenitors into the ischemic hindlimbs of non-diabetic mice improved angiogenic response to a lesser extent $3{ }^{1}$ Moreover, Tepper et al reported that the proliferation and tube formation of EPCs were impaired in patients with type 2 diabetes compared with normal subjects? ${ }^{2}$ Although these studies have clarified an adverse effect of DM on the functional activity of EPCs, the underlying mechanisms remain unsolved.

While, aging or senescence may constitute a potential limitation to the ability of progenitor cells to sustain ischemic tissue and repair. Edelberg et al demonstrated that only the transplantation of young BM-derived cells restored age-associated impaired neovascularization, whereas the $\mathrm{BM}$ of aged mice was not effective ${ }^{33}$ Moreover, the migratory capacity of PB-derived EPCs of elderly patients with CAD is significantly reduced!1,34 These findings highlight a potentially relevant feature of the endogenous repair process and poses an interesting question on the value of therapies based on the increase of endogenous EPC in either elderly patients or patients with atherosclerotic risk factors.

The present study demonstrates that HG induces a reduction of the number of EPCs. Moreover, inhibition of p38 MAPK restored the antiangiogenetic effects of hyperglycemia. The mechanisms by which glucose accelerates the onset of EPC senescence remains to be determined. It has been reported that glucose can activate the p38 MAPK pathway in many cell types, including EPCs, 6.35 Several studies demonstrate that p38 MAPK blockage is associated with increased angiogenesis ${ }^{36-38}$ Keeping these findings in mind, we speculated that glucose accelerates EPC senescence through p38 activation. However, further studies will be needed to clarify our speculation.

In conclusion, we provide evidence that glucose inhibits EPC differentiation via the p38 MAPK pathway. The inhibition of EPC senescence may importantly improve the functional activity of EPCs for potential cell therapy. p38 MAPK has a critical role in EPCs senescence and may represent a sensitive target in a number of angiogenesisrelated disorders including DM.

\section{References}

1. The Diabetes Control and Complications Trial Research Group. The effect of intensive treatment of diabetes on the development progression of long-term complications in insulin-dependent diabetes mellitus. N Engl J Med 1993; 329: 977-986.

2. UK Prospective Diabetes Study (UKPDS) Group. Intensive bloodglucose control with sulphonylureas or insulin compared with conventional treatment risk of complications in patients with type 2 diabetes (UKPDS 33). Lancet 1998; 352: 837-853.

3. Kosuge M, Kimura K, Kojima S, Sakamoto T, Matsui K, Ishihara M, et al. Effects of glucose abnormalities on in-hospital outcome after coronary intervention for acute myocardial infarction. Circ J 2005; 69: $375-379$.

4. Brownlee M. Biochemistry and molecular cell biology of diabetic complications. Nature 2001; 414: 813-820.

5. McGlin S, Saad S, Pronnik CA. High glucose-mediated effects on endothelial cell proliferation occur via p38 MAP kinase. Am J Physiol 2003; 285: E708-E717.

6. Asahara T, Murohara T, Sullivan M, van der Zee R, Li T, Witzenbuchler B, et al. Isolation of putative progenitor endothelial cells to angiogenesis. Science 1997; 275: 964-967.
7. Shi Q, Rafii S, Wu MH, Wijelath ES, Yu C, Ishida A, et al. Evidence for circulating bone marrow-derived endothelial cells. Blood 1998; 92: $362-367$.

8. Kong D, Melo LG, Mangi AA, Zhang L, Lopez-Ilasaca M, Perrella MA, et al. Enhanced inhibition of neointimal hyperplasia by genetically engineered endothelial progenitor cells. Circulation 2004; 109: $1769-1775$.

9. Iwakura A, Luedemann C, Shastry S, Hanley A, Kearney M, Aikawa $\mathrm{R}$, et al. Estrogen-mediated, endothelial nitric oxide synthase-dependent mobilization of bone marrow-derived endothelial progenitor cells contributes to reendotheliazation after arterial injury. Circulation 2004; 108: 3115-3121.

10. Ishida A, Ohya Y, Sakuda H, Ohshiro K, Higashiuesato Y, Nakaema $\mathrm{M}$, et al. Autologous peripheral blood mononuclear cell implantation for patients with peripheral arterial disease improves limb ischemia. Circ J 2005; 69: 1260-1265.

11. Vasa M, Fichtlscherer S, Aicher A, Adler K, Urbich C, Martin H, et al. Number and migratory activity of circulating endothelial progenitor cells inversely correlate with risk factors for coronary artery disease. Circ Res 2001; 89: E1-E7.

12. Choi JH, Kim KL, Huh W, Kim B, Byun J, Suh W, et al. Decreased number and impaired angiogenic function of endothelial progenitor cells in patients with chronic renal failure. Arterioscler Thromb Vasc Biol 2004; 24: 1246-1252.

13. Kondo T, Hayashi M, Takeshita K, Numaguchi Y, Kobayashi K, Iino $\mathrm{S}$, et al. Smoking cessation rapidly increases circulating progenitor cells in peripheral blood in chronic smokers. Arterioscler Thromb Vasc Biol 2004; 24: 1442-1447.

14. Rauscher FM, Goldschmitdt-Clermont PJ, Davis BH, Wang T, Gregg $\mathrm{D}$, Ramaswami $\mathrm{P}$, et al. Aging, progenitor cell exhaustion, and atherosclerosis. Circulation 2003; 108: 457-463.

15. Scheubal RJ, Zorn H, Silber RE, Kuss O, Morawietz H, Holtz J, et al. Age-dependent depression in circulating endothelial progenitor cells in patients undergoing coronary artery bypass grafting. $J \mathrm{Am}$ Coll Cardiol 2003; 42: 2073-2080.

16. Schmidt-Lucke C, Rossig L, Fichtlscherer S, Vasa M, Britten M, Kamper U, et al. Reduced number of circulating endothelial progenitor cells predicts future cardiovascular events: Proof of concept for the clinical importance of endogenous vascular repair. Circulation 2005; 111: $2981-2987$.

17. Heiss C, Keymel S, Niesler U, Ziemann J, Kelm M, Kaika C. Impaired progenitor cell activity in age-related endothelial dysfunction. J Am Coll Cardiol 2005; 45: 1441-1448.

18. Imanishi T, Hano T, Matsuo Y, Nishio I. Oxidized LDL inhibits vascular endothelial growth factor-induced endothelial progenitor cell differentiation. Clin Exp Pharmacol Physiol 2003; 30: 665-670.

19. Imanishi T, Hano T, Nishio I. Angiotensin II potentiates VEGF-induced proliferation, and network formation in endothelial progenitor cells. Hypertension Res 2004; 27: 101-108.

20. Dimri GP, Lee X, Basile G, Acosta M, Scott G, Roskelly C, et al. A biomarker that identifies senescent human cells in culture and in aging skin in vitro. Proc Natl Acad Sci USA 1995; 92: 9363-9367.

21. Strauer BE, Brehm M, Zeus T, Köstering M, Hernandez A, Sorg RV, et al. Repair of infarcted myocardium by autologous intracoronary mononuclear bone marrow cell transplantation in humans. Circulation 2002; 106: 1913-1918.

22. Esato K, Hamano K, Li TS, Furutani A, Seyama A, Takenaka H, et al. Neovascularization induced by autologous bone marrow cell implantation in peripheral arterial disease. Cell Transplant 2002; 11: $747-$ 752.

23. Stamm C, Westphal B, Kleine HD, Petzsch M, Kittner C, Klinge H, et al. Autologous bone-marrow stem-cell transplantation for myocardial regeneration. Lancet 2003; 361: 45-46.

24. Tse HF, Kwong YL, Chan JK, Lo G, Ho CL, Lau CP. Angiogenesis in ischaemic myocardium by intramyocardial autologous bone marrow mononuclear cell implantation. Lancet 2003; 361: 47-49.

25. Fuchs S, Satler LF, Kornowski R, Okubagzi P, Weisz G, Baffour R, et al. Catheter-based autologous bone marrow myocardial injection in no-option patients with advanced coronary artery disease: A feasibility study. J Am Coll Cardiol 2003; 41: 1721-1724.

26. Perin EC, Dohmann HF, Borojevic R, Silva SA, Sousa AL, Mesquita $\mathrm{CT}$, et al. Transendocardial, autologous bone marrow cell transplantation for severe, chronic ischemic heart failure. Circulation 2003; 107: 2294-2302.

27. Kang HJ, Kim HS, Zhang SY, Park KW, Cho HJ, Koo BK, et al. Effects of intracoronary infusion of peripheral blood stem-cells mobilised with granulocyte-colony stimulating factor on left ventricular systolic function and restenosis after coronary stenting in myocardial infarction: The MAGIC cell randomised clinical trial. Lancet 2004; 363: $751-756$. 
28. Wollert KC, Meyer GP, Lotz J, Ringes-Lichtenberg S, Lippolt P, Breidenbach $\mathrm{C}$, et al. Intracoronary autologous bone-marrow cell transfer after myocardial infarction: The BOOST randomised controlled clinical trial. Lancet 2004; 364: 141-148.

29. Stamm C, Kleine HD, Westphal B, Petzsch M, Kittner C, Nienaber $\mathrm{CA}$, et al. CABG and bone marrow stem cell transplantation after myocardial infarction. Thorac Cardiovasc Surg 2004; 52: 152-158.

30. Higashi Y, Kimura M, Hara K, Noma K, Jitsuiki D, Nakagawa K, et al. Autologous bone-marrow mononuclear cell implantation improves endothelium-dependent vasodilation in patients with limb ischemia. Circulation 2004; 109: 1215-1218.

31. Tamarat R, Silvestre JS, Le Ricousse-Roussanne S, Barateau V, Lecomte-Raclet L, Clergue M, et al. Impairment in ischemia-induced neovascularization in diabetes: Bone marrow mononuclear cell dysfunction and therapeutic potential of placenta growth factor treatment. Am J Pathol 2004; 164: 457-466.

32. Tepper OM, Galiano RD, Capla JM, Kalka C, Gagne PJ, Jacobowitz GR, et al. Human endothelial progenitor cells from type II diabetics exhibit impaired proliferation, adhesion, and incorporation into vascular structures. Circulation 2002; 106: 2781-2786.
33. Edelberg JM, Tang L, Hattori K, Lyden D, Rafii S. Young adult bone marrow-derived endothelial precursor cells restore aging-impaired cardiac angiogenic function. Circ Res 2002; 90: E89-E93.

34. Hill JM, Zalos G, Halcox JP, Schenke WH, Waclawiw MA, Quyyumi AA, et al. Circulating endothelial progenitor cells, vascular function, and cardiovascular risk. N Engl J Med 2003; 348: 593-600.

35. Seeger FH, Haendeler J, Walter DH, Rochwalsky U, Reinhold J, Urbich C, et al. p38 mitogen-activated protein kinase downregulates endothelial progenitor cells. Circulation 2005; 111: 1184-1191.

36. Adams RH, Porras A, Alonso G, Jones M, Vinterstewn K, Panelli S, et al. Essential role of p38a MAP kinase in placental but not embryonic cardiovascular development. Mol Cell 2000; 6: 106-116.

37. Matsumoto T, Turesson I, Book M, Gerwins P, Claesson-Welsh L. p38 MAP kinase negatively regulates endothelial cell survival, proliferation, and differentiation in FGF-2-stimulated angiogenesis. J Cell Biol 2002; 156: 149-160.

38. Gratton JP, Morales-Ruiz M, Kureishi Y, Fulton D, Walsh K, Sessa WC. Akt down-regulation of p38 signaling provides a novel mechanism of vascular endothelial growth factor-mediated cytoprotection in endothelial cells. J Biol Chem 2001; 276: 30359-30365. 